\title{
Hepatitis B DNA Measurement
}

National Cancer Institute

\section{Source}

National Cancer Institute. Hepatitis B DNA Measurement. NCI Thesaurus. Code C103404.

The determination of the amount of hepatitis B virus DNA in a sample. 